\title{
Coal mine tailings: development after revegetation with salt- tolerant tree species
}

\author{
A.V. Spain School of Earth and Environment, The University of Western Australia \\ M. Tibbett Department of Environmental Science and Technology, Cranfield University, UK
}

\begin{abstract}
Coal mine tailings are often hostile media in which to grow plants. This paper reports selected physical and chemical properties of alkaline saline-sodic tailings 1.4 and 9.4 years after deposition in three experimental tailings storage facilities (TSFs). This study included the effects on the tailings of three moderately salttolerant tree species grown on their surfaces during the last 7.6 years of this period.

Few changes occurred to the physical properties of the vegetated or unvegetated tailings over this period apart from strength increases associated with drying and settling. Chemical changes over this period included lower salinity (as EC), Na and S concentrations beneath the tree canopies which were associated with reduced site irradiance. No pedologically meaningful changes to properties reflecting soil organic matter or the concentrations of other elements were apparent. It is concluded that meaningful pedological development in these wastes is likely to require lengthy periods.

The tailings materials of a seasonal wetland studied in one of the TSFs showed materials differences due to deposition of non-tailings materials eroded from upslope. Salinity was substantially reduced in the nearsurface materials due to extensive leaching and lower $C$ and $N$ concentrations indicated a reduced organic matter content; further, the lower C:N ratio may indicate a different type of organic matter associated with the wetland vegetation present.

It is concluded that for successful direct rehabilitation of tailings, careful evaluation is required of the physical, chemical and biological properties that potentially limit plant growth. The plant species to be initially established must be chosen for their tolerance of potentially growth limiting properties, particularly extremes of $\mathrm{pH}$ and salinity. Where tailings properties exceed tolerance limits of the species to be established or plant nutrient element supply limits growth, the materials may need to be ameliorated. In the field, particular attention to drainage of these fine-textured materials is critical to plant success. Pedological development of these fine-textured wastes is considered to require extended time periods, even under optimal conditions.
\end{abstract}

\section{Introduction}

Coal tailings are most commonly disposed of as aqueous slurries into tailings storage facilities (TSFs), where they have potential to cause safety and environmental problems. When first deposited into TSFs, such tailings have very low surface bearing strengths and may remain hazardous to humans, domestic stock and wildlife for lengthy periods (Chapman et al., 1995; Fourie, 2009). Percolation of associated waters may lead to contamination of aquifers and surface waters and extended drying times have been estimated on the basis of laboratory tests. On drying, dust may be generated from their surfaces (Kon et al., 2007) and they may also be subject to spontaneous combustion (see, for example, DERM, 1995).

Coal tailings are difficult to rehabilitate directly since they are fine-textured materials and may possess physical and chemical properties inimical to the growth and development of plants and their associated beneficial micro-organisms. Rehabilitation solutions therefore necessitate control of drainage and commonly dictate covers of various types and thicknesses (see, for example, Fourie and Tibbett, 2007). 
The post-depositional evolution of tailings landforms and their materials properties appears to be poorly known, even over relatively short time frames. If landforms constructed of processing wastes and other geological materials are to be developed as self-sustaining ecosystems, there is a need to understand their long-term evolution in relation to materials properties and the combined effects of pedological-biological influences on their development and spatial organisation, particularly on the near-surface materials. These influences include the physical and chemical activities associated with weathering and related processes but include organisms, particularly plants (see, for example, Binkley and Menyailo, 2005; Hobbie et al., 2007) and their symbiotic micro-organisms. They also include free-living micro-organisms and the soil fauna, particularly the activities of the larger soil organisms responsible for the formation of structure and the incorporation of organic materials (Lavelle and Spain, 2001).

This paper reports changes in fine-textured coal tailings placed in three experimental TSFs at Ebenezer Mine for 3,450 days (c. 9.4 years), including 2,791 days (c. 7.6 years) of tree growth. As part of a wider study of rehabilitation at this mine site (Spain et al., 2010a, 2010b; Tibbett et al., 2010), it poses the question 'can self-sustaining ecosystems be successfully established directly on fine-textured coal tailings materials?' This paper specifically asks 'what changes occur to coal tailings landforms during this period and to the properties of the near-surface materials through the presence of a vegetation cover of trees over this period?'.

The work reported here forms part of studies of pedogenetic development of the upper tailings profile (Spain et al., 2010b). Worrall et al. (2008) presented the results of studies of the growth of the three evergreen salt-tolerant tree species studied here (Casuarina glauca, Eucalyptus camaldulensis, Melaleuca quinquenervia) over 2,791 days (c. 7.6 years) on the currently described tailings.

\section{Methods}

The studies reported here were carried out at Ebenezer Mine, located at $27^{\circ} 40^{\prime} \mathrm{S}, 152^{\circ} 40^{\prime} \mathrm{E}$, c. $44 \mathrm{~km}$ southwest of Brisbane. The climate is described as subtropical, with no dry season (Bureau of Meteorology, 2012). Mean rainfall is approximately $864 \mathrm{~mm}$ per year with a summer maximum: mean monthly rainfall exceeds $100 \mathrm{~mm}$ for the months of December to February, declines to a minimum of $29.4 \mathrm{~mm}$ in August and increases subsequently. Estimated actual evapotranspiration follows the same pattern and ranges from 90-110 mm per month in December to February, declining to $20-30 \mathrm{~mm}$ per month between June and August (Bureau of Meteorology, 2012).

The three experimental TSFs (Worrall et al., 2008) were constructed in early January 1998 and ranged in size from 960 to $2,070 \mathrm{~m}^{2}$; they were filled with an aqueous slurry of fine-textured tailings in the same month. They were excavated to maximum depths of $4.5 \mathrm{~m}$ within a landform constructed of mixed salinesodic overburden spoil ('waste rock') (Spain and Tibbett, 2011); because of their angled internal batters, the TSFs were shallower towards the edges. Low above-grade walls were built of the same materials. These TSFs virtually comprise their own catchments, with only small contributions from their surrounds. All three TSFs retained input rainwater for periods during the wet season: TSFs 1 and 3 hold water for extended periods and have developed seasonal wetland plant communities dominated by Typha sp. (Typhaceae) while TSF 2 holds water for lesser periods and has no wetland community.

Areas of TSFs 1 and 3 were planted (mostly at a $3 \mathrm{~m}$ by $3 \mathrm{~m}$ spacing) to three salt-tolerant native tree species on 29 October 1999 (Worrall et al., 2008). Of these three species, C. glauca has high salt tolerance (root zone ECe 8-16 dS m ${ }^{-1}$; E. camaldulensis and $M$. quinquenervia, both have moderate salt tolerance (root zone ECe 4-8 dS $\mathrm{m}^{-1}$ ) (Marcar and Crawford, 2004). Ineffective drainage led to extensive mortality in trees planted in the lower parts of these TSFs (Worrall et al., 2008) and while these areas were subsequently used to infer potential changes in unvegetated tailings, it is likely that they experienced greater leaching than those more elevated. 
Initial sampling of the tailings $(0-0.10 \mathrm{~m})$ was based on sampling conducted in June 1999, 1.42 years (519 days) after tailings deposition and these were subsequently analysed for selected chemical and particle size properties. On 19 June 2007, near-surface $(0-3 \mathrm{~cm}$ depth) tailings associated with the trees in TSFs 1 and 3 were sampled in relationship to their distances from three individuals of the three tree species listed above: $0-0.25 \mathrm{~m}$ from the stem, the $0.25 \mathrm{~m}$ lateral interval located mid-way between the stem and the canopy margin, the $0.25 \mathrm{~m}$ immediately inside the canopy margin and from $0.50-0.75 \mathrm{~m}$ beyond the canopy margin. Further samples $(0-3 \mathrm{~cm})$ were taken in unvegetated areas where tree mortality had occurred due to insufficient drainage. On 14 September 2007, three near-surface $(0-2 \mathrm{~cm})$ tailings samples were taken from the seasonal wetland at the lowest point of TSF 3. At this time, four pits in TSF 1 were sampled; information from samples taken between 0.75 and $1.50 \mathrm{~m}$ deep was used to permit comparison of the properties of the sub-surface materials with those near the surface.

Particle size distributions were measured by sieving for the sand fractions and by the pipette and sieve method for those finer (Coventry and Fett, 1979). The following were measured using procedures described in Rayment and Higginson (1992): $\mathrm{pH}$ (in $0.01 \mathrm{M} \mathrm{CaCl}_{2}$, at a 1:5 soil-solution ratio), salinity was measured as $\mathrm{EC}$ at a 1:5 soil-solution ratio (EC 1:5). Saturated paste equivalent (ECe) was estimated from EC 1:5 using a multiplier (8.5) based on the light clay field texture (Hazleton and Murphy, 2007). Cation exchange capacity (CEC) and exchangeable basic cation concentrations were measured using the compulsive exchange method with a pre-washing to remove soluble salts (Rayment and Higginson, 1992). Mineralogy of the $<2 \mathrm{~mm}$ fraction was determined by X-ray diffraction analysis. Free swell was measured using the American Colloid Company procedure (Kajita, 1997). Total C and total $\mathrm{N}$ were determined using a Leco furnace. Concentrations of other total elements were determined using XRF analysis, neutron activation analysis (NAA) or by ICP-AES determination following acid digestion and appropriate dilution.

Air-dried coal tailings sampled from TSFs 1 and 3 were subjected to a modified 'Toxicity Characteristic Leaching Procedure' (TCLP) test (EPA, 1986). The test involved leaching $100 \mathrm{~g}$ of tailings material in 2 litres of an acetic acid solution ( $5.7 \mathrm{ml}$ glacial acetic acid per litre water, $\mathrm{pH} 2.88$ ) by tumbling in a rotary extractor device for 18 hours at $30 \mathrm{rpm}$. This was followed by filtration $(0.45 \mu \mathrm{m})$ and measurement of elemental concentrations by ICP-AES.

Observations were made during 2007 of erosion of the TSF walls, deposition of transported materials and the surface properties of the tailings materials. Structural phenomena in the upper tailings profiles were described from four pits dug in TSF 1 to maximum depths of c. $1.50 \mathrm{~m}$, from surface observations made in the three TSFs and in the adjacent main mine TSF.

Where statistical comparisons were made using analysis of variance, appropriate data transformations were applied. Mann-Whitney non-parametric tests were used where data properties did not conform to the requirements of parametric methods.

\section{$3 \quad$ Results and discussion}

\subsection{Materials properties}

Based on a sampling of the near-surface materials, physical and chemical properties of the tailings are presented from the two sampling occasions, from unvegetated and vegetated sites, from the wetland in TSF 3 and from the four pits dug in TSF 1.

\subsubsection{Selected tailings properties determined 1.4 years post deposition}

Based on three near-surface $(0-0.10 \mathrm{~m})$ samples taken from each TSF in June 1999, the mean mass of the $<2 \mathrm{~mm}$ fraction was $82.2 \%$ of total sample weight $(\mathrm{se} 6.6, \mathrm{n}=9$ ). The mean particle size distribution of the $<2 \mathrm{~mm}$ fraction is presented in Table 1. The field texture of the materials approximates to a light clay (McDonald and Isbell, 1998). 
The mineral composition of the $<2 \mathrm{~mm}$ fraction of the tailings is dominated by smectite (34-49\%) and kaolinite (31-34\%) with substantial quartz (18-20\%) also present. Despite the appreciable smectite present, the tailings materials swelled on hydration by only 10 to $20 \%$ of a standard smectite sample.

Table 1 Proportions by weight (means and standard errors) of the components of the $<2 \mathrm{~mm}$ fraction of the tailings $(n=9)$

\begin{tabular}{ccccc}
\hline & Coarse Sand & Fine Sand & Silt & Clay \\
& $\mathbf{2 0 0 - 2 , 0 0 0 ~} \boldsymbol{\mu m}$ & $\mathbf{2 0 - 2 0 0} \boldsymbol{\mu m}$ & $\mathbf{2 - 2 0} \boldsymbol{\mu m}$ & $<\mathbf{m m}$ \\
\hline Mean & 12.4 & 27.5 & 25.8 & 34.4 \\
se & 2.4 & 2.6 & 2.0 & 1.7 \\
\hline
\end{tabular}

The tailings materials are strongly alkaline (Table 2). The mean equivalent saturated paste EC (ECe) was estimated to be $15 \mathrm{dS} \mathrm{m}^{-1}$, which indicates that plants require a high salinity adaptation to succeed on these tailings plants (Marcar and Crawford, 2004). The high salinity of the near-surface tailings may partially reflect the elevated values of the near-surface capillary fringe. Consistent with the substantial presence of fine coal particles noted, total $\mathrm{C}$ and $\mathrm{N}$ concentrations in tailings were higher than occur in most Australian predominantly mineral soils (Spain et al., 1983). Mean tailings C: $\mathrm{N}$ ratio is also high in this situation because of the presence of an unknown proportion of non-reactive carbon. Mean bicarbonate-extractable P (Olsen P) concentrations were all less than $5 \mathrm{mg} \mathrm{kg}^{-1}$.

Table $2 \mathrm{pH}$, EC 1:5, total C, total $\mathrm{N}$ and the $\mathrm{C}: \mathrm{N}$ ratio of near-surface $(0-0.10 \mathrm{~m})$ tailings materials (means and standard errors) from three experimental TSFs, June 1999

\begin{tabular}{cccccc}
\hline Statistic & $\begin{array}{c}\text { pH 1:5 } \\
\mathbf{C a C l}_{\mathbf{2}}\end{array}$ & $\begin{array}{c}\mathrm{EC} \mathrm{1:5} \\
\mathrm{dS} \mathrm{m}^{-\mathbf{1}}\end{array}$ & $\begin{array}{c}\text { Total C } \\
\mathbf{( \% )}\end{array}$ & $\begin{array}{c}\text { Total N } \\
\text { (\%) }\end{array}$ & C:N \\
\hline Mean & 8.22 & 1.74 & $\mathbf{1 9 . 7}$ & 0.38 & 51 \\
se & 0.14 & 0.10 & 1.1 & 0.03 & 1 \\
$\mathrm{n}$ & 9 & 9 & 14 & 14 & 14 \\
\hline
\end{tabular}

The cation exchange capacity (CEC), of the tailings (measured as the effective CEC, or ECEC) (Table 3), is moderate and perhaps lower than expected, given the dominant smectites. By soil standards (Hazleton and Murphy, 2007), exchangeable $\mathrm{Ca}^{2+}$ is moderate and less than exchangeable $\mathrm{Mg}^{2+}$, which is high; exchangeable $\mathrm{K}^{+}$is low and exchangeable $\mathrm{Na}^{+}$is very high. The exchangeable $\mathrm{Na}^{+}$percentage (ESP, or exchangeable $\mathrm{Na}^{+}$expressed as a \% of ECEC) was also high and variable (range 13 to 38 ) and all materials analysed were strongly sodic.

Table 3 Exchange properties $\left(\mathrm{cmol} \mathrm{kg}^{-1}\right)$ (means and standard errors) of near-surface tailings samples $(n=9)$

\begin{tabular}{|c|c|c|c|c|c|c|c|}
\hline \multirow[t]{2}{*}{ Statistic } & \multicolumn{4}{|c|}{ Exchangeable Basic Cations } & \multirow[t]{2}{*}{ ECEC } & \multirow[t]{2}{*}{ ESP } & \multirow[t]{2}{*}{ CEC } \\
\hline & $\mathrm{Ca}^{2+}$ & $\mathrm{Mg}^{2+}$ & $\mathrm{K}^{+}$ & $\mathrm{Na}^{+}$ & & & \\
\hline Mean & 4.55 & 5.69 & 0.23 & 2.57 & 13.0 & 26 & 16 \\
\hline se & 1.31 & 1.60 & 0.05 & 0.45 & 3.3 & 3 & 1 \\
\hline
\end{tabular}

The total concentrations of 30 elements in tailings of the three experimental TSFs are presented in Table 4. Concentrations of $\mathrm{Al}$ and $\mathrm{Na}$ are high in terms of world soils (non-saline soils only) although $\mathrm{P}$ and $\mathrm{Si}$ are low (Kabata-Pendias and Mukherjee, 2007; Kabata-Pendias, 2011). Concentrations of the remaining elements all fell within the ranges reported for world soils. The concentrations in the tailings of some contaminant 
elements present in the waters of the main mine TSF, notably Se and Mo, were less than detection limits of the analytical methods used.

Table 4 Total element concentrations ( $\mathrm{mg} \mathrm{kg}^{-1}$, unless otherwise indicated) in tailings samples taken from the three experimental TSFs and from the main mine TSF (Chapman et al., 1995)

\begin{tabular}{cccccc}
\hline Element & Mean & se & Element & Mean & Std Dev. \\
& Concentrations Determined By ICP AES ( $\mathbf{n = 5})$ & \\
\hline Ca (\%) & +1.45 & - & Cu & $\dagger 33$ & - \\
K (\%) & 0.55 & 0.04 & Mg (\%) & +0.58 & - \\
Na (\%) & 0.50 & 0.04 & & & \\
& Concentrations Determined By NAA ( $\mathbf{n}=5)$ & \\
As & 2.45 & 0.25 & Ba & 228 & 29 \\
Br & 6.67 & 0.86 & Ce & 47.4 & 1.8 \\
Co & 5.94 & 0.55 & Cr & 13.48 & 1.00 \\
Cs & 4.87 & 0.38 & Eu & 1.05 & 0.08 \\
Fe (\%) & 1.18 & 0.31 & Hf & 4.08 & 0.20 \\
La & 20.70 & 0.84 & Lu & 0.27 & 0.01 \\
Rb & 25.30 & 3.22 & Sb & 0.44 & 0.08 \\
Sc & 12.44 & 0.21 & Sm & 4.88 & 0.18 \\
Th & 8.58 & 0.32 & U & $\dagger 1.37$ & - \\
Yb & 1.82 & 0.06 & Zn & +82.8 & - \\
& Single Sample Values From Main TSF & \\
Al (\%) & 10.1 & - & Mn & 30 & - \\
P & 110 & - & S & 580 & - \\
Si (\%) & 20.9 & - & & & \\
\hline
\end{tabular}

Note: Values in the 'Means' column prefixed with an † are medians and indicate that some sample values were less than the detection limit.

\subsubsection{Properties of the near-surface materials 9.4 years after deposition}

Near-surface $(0-3 \mathrm{~cm})$ tailings materials were re-evaluated c. 8 years after the initial sampling, following c. 7.6 years of tree growth on the surfaces. Properties were compared with those of unvegetated areas of the TSFs, the seasonal wetland located at the lowest part of TSF 3 and from the walls of pits dug in TSF 1 (Table 5).

\subsubsection{Below and beyond-canopy locations}

Data from the vegetated areas, including samples taken from $0.50-0.75 \mathrm{~m}$ beyond the canopy margins, were subjected to nested analysis of variance to test for significant differences between species and between locations, nested within species. Significant differences $(P<0.05)$ among species means were limited to concentrations of total $\mathrm{Al}$ and $\mathrm{Mn}$; significant $(P<0.05)$ differences between locations within species were limited to EC 1:5, the $\mathrm{C}: \mathrm{N}$ ratio and total $\mathrm{S}$ concentrations. 
The range in mean $\mathrm{Al}$ concentrations among tailings associated with the three species was less than $1 \%$, with means varying from $6.95 \%$ in those associated with $M$. quinquenervia to $7.94 \%$ in those associated with $C$. glauca. For $\mathrm{Mn}$, the opposite situation pertained with mean values varying from $90 \mathrm{mg} \mathrm{kg}^{-1}$ associated with $C$. glauca up to $155 \mathrm{mg} \mathrm{kg}^{-1}$ in tailings associated with M. quinquenervia. Because of these differences are minor, Table 5 presents mean values calculated over all species.

Posterior tests indicated that small differences in mean EC 1:5 (range 0.18 to $0.96 \mathrm{dS} \mathrm{m}^{-1}$ ) were present among sampling locations beneath the canopy although these were significant $(P<0.05)$ only in tailings associated with $M$. quinquenervia. As indicated in Table 5, the mean EC 1:5 value for the three belowcanopy locations over all species was substantially less than the mean value $\left(1.49 \mathrm{dS} \mathrm{m}^{-1}\right.$, se $\left.0.31, n=9\right)$ for sites located $0.50-0.75 \mathrm{~m}$ beyond the canopy margins, which ranged from 1.41 to $1.58 \mathrm{dS} \mathrm{m}^{-1}$. The mean $\mathrm{C}: \mathrm{N}$ ratios ranged from 41 to 49 over all species and locations; slightly greater values occurred in the halfcanopy and within-canopy-margin locations.

Despite a significant $(P<0.05)$ overall effect of location for the total $\mathrm{S}$ concentrations, posterior tests did not indicate any significant differences $(P<0.05)$ between locations within species. However, as for $E C 1: 5$, the mean value for total $\mathrm{S}$ over the three below-canopy locations was substantially lower $\left(2,431 \mathrm{mg} \mathrm{kg}^{-1}\right)$ than the mean value for all sampling sites from $0.50-0.75 \mathrm{~m}$ beyond the canopy margin $\left(3,928 \mathrm{mg} \mathrm{kg}^{-1}\right.$, se 747 , $n=9)$.

\subsubsection{Comparisons of vegetated and unvegetated areas}

Table 5 presents the properties of tailings sampled at locations distant from the direct effects of vegetation and contrasts these with those taken at the vegetated sites. Where no significant differences $(P<0.05)$ were apparent among the three TSFs, combined values are presented. Where significant differences occurred among the TSFs, the ranges of mean values among the individual TSFs are presented.

Mean $\mathrm{pH} \mathrm{CaCl} 2$ differed by only c. 0.71 units among TSFs, while EC 1:5 differed more markedly. TSF 1 had a significantly higher mean value and was more variable than the remaining two TSFs. TSF 1 also had the highest concentrations of $\mathrm{Na}$ and $\mathrm{S}$, two elements that contribute to salinity. The concentrations of $\mathrm{Ca}$ and $\mathrm{K}$ differed slightly among unvegetated sites although concentrations of the remaining elements did not.

The major differences evident between the vegetated and unvegetated areas were those related to salinity. Site median EC 1:5 values declined in the order: unvegetated areas, areas 0.50 to $0.75 \mathrm{~m}$ beyond the canopy margins, areas below tree canopies; differences between these three groups were all significantly different $(P<0.05$, Mann-Whitney tests). Mean total $\mathrm{Na}$ and $\mathrm{S}$ concentrations were lowest in below canopy areas and the remaining properties determined were either similar or little different.

\subsubsection{Seasonal wetland at the lowest point of TSF 3}

The wetland materials differed in a number of respects from those upslope due partially to acquisition of TSF wall and other materials and to extended leaching. No particle size information was available for the $<2 \mathrm{~mm}$ size fraction of the materials of this site although the mass percentage of this fraction was 78.3 (se 6.39, $n=3$ ), slightly lower than the tailings materials from upslope locations; this is ascribed to acquisition of coarser-textured TSF wall materials. The $\mathrm{pH} \mathrm{CaCl}_{2}$ value differed little from upslope sites while EC 1:5 was markedly lower in the wetland materials. Lower total $\mathrm{C}$ and total $\mathrm{N}$ concentrations indicated lesser organic matter concentrations in the latter materials and the lower $\mathrm{C}: \mathrm{N}$ ratio may indicate qualitatively different organic matter, associated with contributions from the Typha sp. Concentrations of $\mathrm{K}, \mathrm{P}$ and $\mathrm{Si}$ were higher than in upslope locations, those of $\mathrm{Al}, \mathrm{Ca}, \mathrm{Fe}, \mathrm{Mg}$ and $\mathrm{Mn}$ were similar and those of $\mathrm{Na}$ and, particularly S, were lower.

\subsubsection{Estimated salinities in five groupings of sites}

Estimated ECe values are presented (Figure 1) for five groupings of sites, including values from tailings sampled within four pits at depths below $0.75 \mathrm{~m}(n=7)$. The approximate minimum salinity tolerances 
required by plants to grow satisfactorily in media of differing salinities are also presented (Marcar and Crawford, 2004).

Substantial salinity differences existed between the low values of the seasonal wetland and the remaining sites. Among the near-surface sites sampled, salinity increased markedly with increasing site surface irradiance in the order: below-canopy sites to the sites $0.50-0.75 \mathrm{~m}$ beyond the canopy margins to the extremely saline values of the unvegetated tailings. Estimated ECe values in the pits at depths greater than $0.75 \mathrm{~m}$ were similar to sites $0.50-0.75 \mathrm{~m}$ beyond the canopy margins.

Table 5 Descriptive statistics for $\mathrm{pH}\left(\mathrm{CaCl}_{2}\right)$, EC 1:5, the concentrations of total $\mathrm{C}$, total $\mathrm{N}$, the $\mathrm{C}: \mathrm{N}$ ratio, and total concentrations of selected other elements in vegetated, near-surface $(0-3 \mathrm{~cm})$ tailings from TSFs 1 and 3 , unvegetated sites in TSFs 1-3 and a wetland site in TSF 39.4 years after deposition (concentrations \% unless otherwise indicated) (vegetated sites, $n=36$; unvegetated sites, $n=18$; wetland site $n=2$ )

\begin{tabular}{|c|c|c|c|c|c|c|}
\hline \multirow[t]{2}{*}{ Property } & \multicolumn{2}{|c|}{ Vegetated Sites } & \multicolumn{2}{|c|}{ Unvegetated Sites } & \multicolumn{2}{|c|}{ Wetland Site } \\
\hline & Mean & se & Mean & se & Mean & se \\
\hline $\mathrm{pH}\left(\mathrm{CaCl}_{2}\right)$ & 7.36 & 0.08 & $* 7.03-7.74$ & - & 7.55 & 0.04 \\
\hline $\mathrm{EC}\left(\mathrm{dS} \mathrm{m}^{-1}\right)$ & †0.58 & 0.07 & *1.92-4.28 & - & 0.12 & 0.02 \\
\hline C & 24.90 & 0.95 & 23.00 & 1.49 & 7.83 & 0.72 \\
\hline $\mathbf{N}$ & 0.55 & 0.02 & 0.48 & 0.03 & 0.22 & 0.02 \\
\hline C:N & 45 & 1 & 48 & 1 & 35 & 1 \\
\hline Al & 7.53 & 0.15 & 8.06 & 0.34 & 10.47 & 0.18 \\
\hline $\mathrm{Ca}$ & 1.05 & 0.11 & $* 0.40-3.21$ & - & 0.49 & 0.03 \\
\hline $\mathrm{Fe}$ & 1.59 & 0.07 & 1.31 & 0.05 & 1.46 & 0.03 \\
\hline K & 0.68 & 0.03 & *0.592-0.809 & - & 1.03 & 0.01 \\
\hline Mg & 0.48 & 0.02 & 0.50 & 0.02 & 0.70 & 0.02 \\
\hline Mn mg kg ${ }^{-1}$ & 123 & 8 & 99 & 10 & 129 & 26 \\
\hline $\mathrm{Na}$ & 0.28 & 0.01 & $* 0.349-0.644$ & - & 0.19 & 0.01 \\
\hline P mg kg-1 & 187 & 5 & 149 & 7 & 227 & 9 \\
\hline$S \mathrm{mg} \mathrm{kg}{ }^{-1}$ & $+2,431$ & 118 & $* 2,283-3,338$ & - & 677 & 39 \\
\hline $\mathrm{Si}$ & 17.33 & 0.40 & 17.83 & 0.64 & 24.32 & 0.16 \\
\hline
\end{tabular}

* Ranges of means in the three TSFs.

+ excludes samples taken $0.50-0.75 \mathrm{~m}$ beyond the canopy margins, $n=27$

\subsubsection{Compositions of leachates from the tailings materials}

Table 6 presents the concentrations of 17 elements in weak acid tailings leachates. In decreasing order of concentrations, the dominant elements were $\mathrm{Sr}, \mathrm{Br}, \mathrm{Na}, \mathrm{Cl}, \mathrm{Ba}, \mathrm{B}$ and $\mathrm{S}$ and those most likely to be available from leaching of the current tailings. Chloride was present in elevated concentrations in the two leachates indicating its probable physiological importance of this ion in waters associated with the tailings in situ. Present at lower concentrations were $\mathrm{Br}, \mathrm{B}, \mathrm{Ba}, \mathrm{Mo}, \mathrm{Se}, \mathrm{As}, \mathrm{Cd}$, and $\mathrm{Cs}$. The important contaminant elements Se and Mo were present in notable concentrations in the waters of the main mine TSF. 


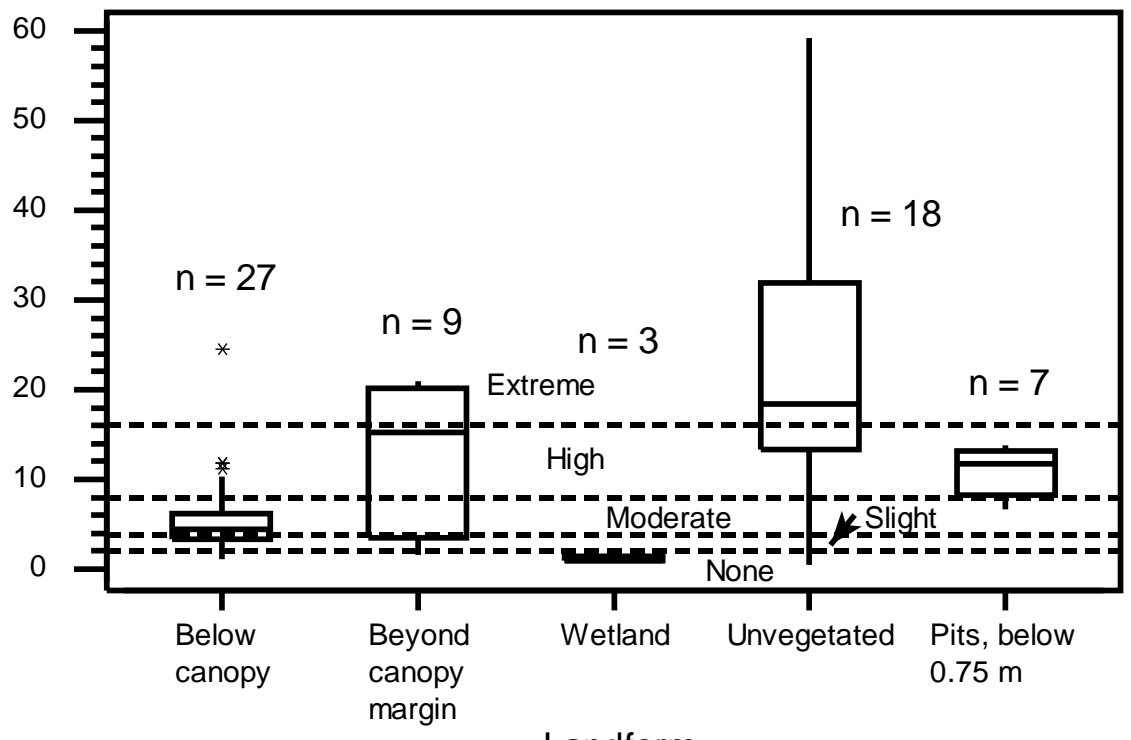

Figure 1 Box and whisker plots of ECe values in five groupings of tailings materials in the experimental TSFs, together with the degree of salinity tolerance necessary for satisfactory growth (see text for explanation)

Table 6 Elemental compositions of weak acid leachates from coal tailings samples

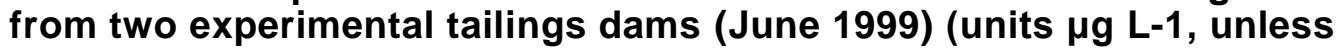
otherwise indicated)

\begin{tabular}{|c|c|c|c|c|c|}
\hline \multirow[t]{2}{*}{ Element } & \multicolumn{2}{|c|}{ Sample Location } & \multirow[t]{2}{*}{ Element } & \multicolumn{2}{|c|}{ Sample Location } \\
\hline & TSF 1 & TSF 3 & & TSF 1 & TSF 3 \\
\hline As & 6.4 & 8.4 & $K\left(\mathrm{mg} \mathrm{L}^{-1}\right)$ & 8.8 & 5.5 \\
\hline B & 220 & 140 & $M g\left(\mathrm{mg} \mathrm{L}^{-1}\right)$ & 14 & 7 \\
\hline $\mathrm{Ba}$ & 220 & 140 & Mo & 130 & 61 \\
\hline $\mathrm{Br}$ & 670 & 250 & $\mathrm{Na}\left(\mathrm{mg} \mathrm{L}^{-1}\right)$ & 500 & 300 \\
\hline $\mathrm{Ca}\left(\mathrm{mg} \mathrm{L}^{-1}\right)$ & 12 & 6.6 & $S\left(\mathrm{mg} \mathrm{L}^{-1}\right)$ & 113 & 54 \\
\hline $\mathrm{Cd}$ & 1.3 & 0.6 & Se & 22 & 69 \\
\hline $\mathrm{Cl}\left(\mathrm{mg} \mathrm{L}^{-1}\right)$ & 440 & 290 & $\operatorname{Sr}\left(\mathrm{mg} \mathrm{L}^{-1}\right)$ & 850 & 330 \\
\hline Cs & 0.2 & $<0.1$ & & & \\
\hline
\end{tabular}

\section{$4 \quad$ Conclusions}

From their initial state as a low-bearing-strength aqueous slurry, the fine-textured Ebenezer coal tailings have, over c. 9.4 years, undergone substantial strength increases with drying, crusting and consolidation to the point where they no longer pose a threat to humans or animals and can support vehicular traffic when dry. This increase in strength has been accompanied by substantial structural and landform changes leading to the development of concave landforms with seasonal wetlands forming at their lowest points (Worrall et al., 2008; Spain et al., 2010b). Erosional and transportational processes have lead to modification of materials at the lowest part of the tailings landforms to form wetland substrates of different physical and chemical properties. The remaining tailings materials showed a limited number of changes in chemical properties consistent with their short period of exposure to soil-forming influences. 


\subsection{Materials properties}

The present tailings materials may be classified as fine-textured, moderately to highly alkaline, moderately to highly saline (Marcar and Crawford, 2004) and strongly sodic (Hazleton and Murphy, 2007), which confirms them as a hostile growing medium for unadapted plants. Nonetheless, largely unfertilised, moderately to highly salt-tolerant tree species have grown adequately on these materials, reaching heights greater than $10 \mathrm{~m}$ in c. 7.6 years of growth and largely stabilising their associated tailings with a combination of near-surface plant litter and roots (Worrall et al., 2008).

Tailings alkalinity implies that some nutrient elements, notably the critical element $P$, will be less available to plants while high salinity substantially limits the survival and growth of unadapted higher plants (Marcar and Crawford, 2004). Salinity levels reported here are extreme in the near-surface evaporative fringe occurring in unvegetated tailings although much lower values occur beneath the substantial litter layers that occur under the tree canopies. Below the surface capillary layer, moderately elevated ECe values indicate that plant species to be grown in these materials must be at least moderately salt tolerant (Marcar and Crawford, 2004). Salinity may be overestimated in the current situation since water soluble and readilyleachable elements present in the tailings may contribute to EC and therefore salinity calculations. The strongly sodic character of the tailings implies instability, dispersion of clays and pore blockage; it also implies the presence of potentially phytotoxic $\mathrm{Na}^{+}$ions.

The present tailings differ in elemental composition from normal soils (Kabata and Mukherjee, 2007; Kabata-Pendias, 2011). The $C$ concentration lies between those of mineral and organic soils although an unknown proportion of the $C$ present in these tails occurs as fine coal and is unavailable to normal soilbased biological processes. Nitrogen concentrations are in the upper part of the range for Australian mineral soils (Spain et al., 1983) and the C: $\mathrm{N}$ ratio also falls between values typical of these two groups of soils. The concentrations of Al are greater than those typical of world soils while, consistent with their highly saline status, total concentrations of both $\mathrm{Na}$ and $\mathrm{S}$ are elevated by the standards of world non-saline soils. Concentrations of $\mathrm{Fe}$ are in the lower part of this range and those of Si are slightly lower than normally found in world soils. Concentrations of the biologically important nutrient element $P$ are particularly low: less than one third of the value considered typical of the globally-low $\mathrm{P}$ concentrations occurring in Australian soils (Norrish and Rosser, 1983). This implies that planted species are likely to respond positively to $P$ addition, at least.

The compositions of leachates derived from the tailings indicates that they may be contributing to contaminant loading in the main tailings dam waters, although mine spoils and other materials are further potential sources (Spain and Hettipathirana, 2000a). In particular, Mo and Se concentrations were substantial in the leachates and were also high (respectively, 46 to $100 \mu \mathrm{g} \mathrm{L}^{-1}$ and 5.6 to $11.6 \mu \mathrm{g} \mathrm{L}^{-1}$ ) in TSF waters (Spain and Hettipathirana, 2000b) and have the potential to cause significant food chain effects (Smith, 1998).

Apart from strength increases associated with drying and settling, differentiation of the lower parts of two of the TSFs to form seasonal wetlands may represent the greatest change in tailings properties that has occurred during the c. 9.4 year period since deposition. The substantially lower C:N ratio of the wetland indicates the presence of a qualitatively different organic matter in this area and the P concentration was also slightly higher than in the surrounding tailings. Other reported changes in the tailings over the period following deposition and tree growth are relatively minor or of little ecological significance.

Variation in most properties was substantial at a range of scales. The three TSFs differed in a number of properties and sample variability was high at all locations in nearly all of the measured properties. Because of this, many of the small changes that occurred in the chemical properties of the tailings materials that could be ascribed to the presence of the trees must be regarded as indicative: pedologically and ecologically meaningful changes to materials properties are expected to take a substantially longer period to emerge. 


\subsection{Implications for rehabilitation}

Phytoremediation has been shown to be an ecologically sound and cost-effective way to rehabilitate a wide range of post-mining landforms (Weiersbye, 2007; Mendez and Maier, 2008). It may be used as a way to rehabilitate sites prior to relinquishment or, particularly where trees are used, as a technique to accelerate substrate drying, to protect ground and surface waters and perhaps in suppress dust. However, careful control of drainage is required to avoid extended periods of inundation and therefore hypoxia-related mortality (Worrall et al., 2008), especially where fine-textured materials are present.

Since many tailings possess properties that are likely to cause stress in unadapted plants, detailed evaluation of properties important to successful plant growth is necessary and, for rehabilitation purposes, careful species selection is required in relation to such properties. Further, appropriate fertilisation (notably with $\mathrm{P}$ ) is likely to be required and, where substrate conditions are extreme, other forms of amelioration such as $\mathrm{pH}$ adjustment considered. The use of deep-rooting tree species (notably eucalypts) has advantages over grasses in terms of deeper and more rapid drying and probably dust suppression. As judged by their capacity to stabilise slopes (see, for example, Gray, 1995), where strongly rooting trees are successfully grown their roots are likely to provide stronger mechanical reinforcement of substrates than grasses. Nonetheless, depending on their growth habits, certain grasses are offer an effective stabilisation of surface materials and some are also known to be deep rooted (Fisher et al., 1994).

A longer-term problem with fine-textured materials such as the present tailings is that seasonal saturation from flooding during and for a variable interval after the higher summer rainfall season will lead to extended periods of low oxygen concentrations (hypoxia) in near-surface materials. This will be prolonged at least during the initial part of seasonal drying. During this latter period, high capillary rise in these finetextured materials will lead to extended periods of low oxygen concentrations and elevated solute concentrations in near-surface materials. In these and other flooded saline materials, hypoxia interacts with salinity to create greater stress in the existing vegetation beyond that due to either effect alone (BarrettLennard, 2003). Such conditions also lead to poor recruitment from seeds both of plant species be sown by man and those spread to the sites by wind or animals and may make the recruitment of future generations of trees from seed problematic. Provision of a partial or complete layer of coarse-textured materials may serve to create a more favourable environment for the establishment of volunteer plants although such a layer need not be thick.

While substantial physical change was clear in the increased strength and structural formation that occurred with drying, minimal chemical change to the upper tailings materials was apparent following $\mathrm{c}$. 7.5 years of tree growth. Measured chemical changes in the tailings that could be ascribed to the presence of vegetation appear largely limited to reduction of the saline capillary fringe beneath the tree canopies. This may also be reflected in the composition of salts present in the near-surface layer. Other limitations to plant growth may be addressed through substrate amelioration (especially of growth limiting $\mathrm{pH}$ conditions) and nutrient deficiencies addressed through experimental determination of fertiliser requirements.

No meaningful changes in $\mathrm{C}$ or $\mathrm{N}$ concentrations (or in the $\mathrm{C}: \mathrm{N}$ ratio) were apparent, despite the 7.5 years of successful tree growth and the formation of substantial litter layers (Worrall et al., 2008). While fungal hyphae were abundant in the litter layers, there was little indication of the biologically mediated incorporation of litter into the surface tailings material that occurs in normal soils. Changes to tailings properties that would reveal incipient pedogenesis seem more likely to be reflected in properties reflecting microbiological activity.

Although longer term changes to substrate properties following from on-going ecosystem and pedogenetic development appear inevitable (Fourie and Tibbett, 2007; Fourie et al., 2012), pedogenetic development in these materials as reflected in the present suite of chemical properties must be regarded as minimal and considerable time periods will be required for meaningful substrate development to emerge. This contrasts with the situation in coarser-textured, free-draining materials where ecologically and pedologically significant substrate changes can emerge within a few years (see, for example, Spain et al., 2006). 


\section{References}

Barrett-Lennard, E. (2003) The interaction between waterlogging and salinity in higher plants: causes, consequences and implications, Plant and Soil, 253, pp. 35-54.

Binkley, D. and Menyailo, O. (2005) Gaining insights on the effects of tree species on soils, Tree Species Effects on Soils: Implications for Global Change, D. Binkley and O. Menyailo (eds), Kluwer, Dordrecht, pp. 1-16.

Bureau of Meteorology (2012) Australian Government Bureau of Meteorology. Summary statistics Amberley AMO, viewed 15 May 2012, http://reg.bom.gov.au/climate/averages/tables/cw_040004.shtml.

Chapman, B., Milnes, A.R., Carras, J.N., Corbett, L.W., Kirby, J.M., Soole, K.P., Spain, A.V. and Wright, M. (1995) Report on rehabilitation research program at Ebenezer Coal Mine, Willowbank, Queensland, unpublished report, CSIRO Minesite Rehabilitation Research Program, Adelaide.

Coventry, R.J. and Fett, D.E.F. (1979) A pipette and sieve method of particle-size analysis and some observations on its efficiency, CSIRO Division of Soils, Divisional Report No. 38, 26 pp.

DERM (1995) Department of Environment and Resource Management, Rehabilitation of spontaneous combustion areas. viewed 16 May 2012, http://www.derm.qld.gov.au/register/p01206av.pdf), http://www.ehp.qld.gov.au/land/mining/pdf/techguidelines-env-management-mining-d-3.pdf.

EPA (1986) Environmental Protection Agency, Toxicity characteristic leach procedure, Federal Register, 51, No. 114, June 13 1986, (Proposed rules - Part 261 - Appendix 11), viewed 16 May 2012, http://www.epa.gov/wastes/hazard/tsd/permit/tsdregs/frns/51fr21648.pdf.

Fisher, M.J., Rao, I.M., Ayarza, M.A., Lascano, C.E., Sanz, J.I., Thomas, R.J. and Vera, R.R. (1994) Carbon storage by introduced deeprooted grasses in the South American savannas, Nature, Vol. 371, pp. 236-238.

Fourie, A.B. (2009) Preventing catastrophic failures and mitigating environmental impacts of tailings storage facilities, Procedia Earth and Planetary Science, 1(1), pp. 1067-1071.

Fourie, A.B. and Tibbett, M. (2007) Engineering a biological system, in Proceedings: Second International Seminar on Mine Closure (Mine Closure 2007), A.B. Fourie, M. Tibbett and J.V. Wiertz (eds), 16-19 October 2007, Santiago, Chile, Australian Centre for Geomechanics, Perth, pp. 3-12, ISBN 978-0-9804185-0-7.

Fourie, A.B., Tibbett, M. and De Jong, J. (2012) The fallacy of designing for in-perpetuity: geotechnical presumptions, ecosystem responses and concepts for managing inevitable change, in Proceedings Seventh International Conference on Mine Closure (Mine Closure 2012), A.B. Fourie and M. Tibbett (eds), 25-27 September 2012, Brisbane, Australia, Australian Centre for Geomechanics, Perth, pp. 127-136.

Gray, D.H. (1995) The influence of vegetation on the stability of slopes, Vegetation and Slopes: Stabilisation, Protection and Ecology, D.H. Barker (ed), Thomas Telford Services, London, pp. 2-25.

Hazleton, P. and Murphy, B. (2007) Interpreting soil test results, What Do All the Numbers Mean?, CSIRO Publishing, Collingwood, Victoria, $152 \mathrm{p}$.

Hobbie, S.E., Ogdahl, M., Chorover, J., Chadwick, O.A., Oleksyn, J., Zytkowiak, R. and Reich, P.B. (2007) Tree species effects on soil organic matter dynamics: the role of soil cation composition, Ecosystems, Vol. 10, pp. 999-1018.

Kabata-Pendias, A. (2011) Trace elements in soils and plants, 4th edition, CRC Press, Boca Raton, 520 p.

Kabata-Pendias, A. and Mukherjee, A.B. (2007) Trace elements from soil to human, Springer, Berlin, $550 \mathrm{p}$.

Kajita, L.S. (1997) An improved contaminant resistant clay for environmental clay liner applications, Clays and Clay Minerals, Vol. 45, pp. 609-617.

Kon, L.C., Durucan, S. and Korre, A. (2007) The development and application of a wind erosion model for the assessment of fugitive dust emissions from mine tailings dumps, International Journal of Mining, Reclamation and Environment, Vol. 21, pp. 198218.

Lavelle, P. and Spain, A.V. (2001) Soil ecology, Kluwer Academic Publications, Dordrecht, 654 p.

McDonald, R.C. and Isbell, R.F. (1998) Soil profile, Australian Soil and Land Survey Field Handbook, 2nd edition, reprinted, Australian Collaborative Land Evaluation Project, Canberra, pp. 103-152.

Marcar, N.E. and Crawford, D.F. (2004) Trees for saline landscapes, Rural Industries Research and Development Corporation, Barton, ACT, $235 \mathrm{p}$.

Mendez, M.O. and Maier, R.M. (2008) Phytostabilization of mine tailings in arid and semiarid environments-an emerging remediation technology, Environmental Health Perspectives, Vol. 116, pp. 278-283.

Norrish, K. and Rosser, H. (1983) Mineral phosphate, Soils: An Australian Viewpoint, Division of Soils, CSIRO, Melbourne and Academic Press, London, pp. 335-361.

Rayment, G.E. and Higginson, F.R. (1992) Australian laboratory handbook of soil and water chemical methods, Inkata Press, Melbourne, $330 \mathrm{p}$.

Smith, R.E.W. (1998) Preliminary Assessment of the ecotoxicology of tailings dam water at the Ebenezer Coal Mine, Willowbank, Queensland, CSIRO Exploration and Mining Report No. 543C, 20 p.

Spain, A.V. and Hettipathirana, T.D. (2000a) Properties of waters, selected spoil and overburden materials from the Purga Pit, Ebenezer Mine, Willowbank, Queensland, CSIRO Land and Water consultancy report to Ebenezer Mining Company, $94 \mathrm{p}$.

Spain, A.V. and Hettipathirana, T.D. (2000b) Concentrations of selected elements and other properties of the tailings dam waters, Ebenezer Mine, Willowbank, Queensland, CSIRO Land and Water consultancy report to Ebenezer Mining Company, $24 \mathrm{p}$.

Spain, A.V. and Tibbett, M. (2011) Substrate conditions, root and arbuscular mycorrhizal colonisation of landforms rehabilitated after coal mining, sub-tropical Queensland, in Proceedings Sixth International Conference on Mine Closure (Mine Closure 
2011), A.B. Fourie, M. Tibbett and A. Beersing (eds), 19-21 September 2011, Lake Louise, Canada, Australian Centre for Geomechanics, Perth, Vol. 1, pp. 199-208

Spain, A.V., Isbell, R.F. and Probert, M.E. (1983) Organic matter contents of Australian soils, Soils: An Australian Viewpoint, CSIRO, Melbourne/Academic Press, London, pp. 551-563.

Spain, A.V., Tibbett, M. and Worrall, R. (2010a) Land rehabilitation studies at the Ebenezer Mine, Ipswich, Queensland - 1998 to 2007. Volume I: The soils and near-surface wastes of selected rehabilitated waste rock dumps at Ebenezer Mine, unpublished report to Idemitsu Australia Resources Pty Ltd, Brisbane, Centre for Land Rehabilitation, The University of Western Australia, report reference: CLR-10-01-C/CSIRO Earth Sciences and Resource Engineering, Report: EP106663, 185pp., ISBN: 978-1-74052-198-7).

Spain, A.V., Tibbett, M., Smernik, R.J. and Worrall, R. (2010b) Land rehabilitation studies at the Ebenezer Coal Mine, Ipswich, Queensland - 1998 to 2007, Volume II: Ebenezer tailings: experimental landforms, materials properties, pedogenic activity and tree growth, unpublished report to Idemitsu Australia Resources Pty Ltd, Brisbane, report reference CLR-10-02-C, Centre for Land Rehabilitation, University of Western Australia, Report Reference CLR-10-02-C/CSIRO Earth Sciences and Resource Engineering, Report EP106664, 300pp., ISBN: 978-1-74052-199-4.

Spain, A.V., Hinz, D.A., Ludwig, J., Tibbett, M. and Tongway, D. (2006) Mine closure and ecosystem development: Alcan Gove bauxite mine, NT, Australia, in Proceedings First International Seminar on Mine Closure (Mine Closure 2006), A.B. Fourie and M. Tibbett (eds), 13-15 September 2006, Perth, Australia, Australian Centre for Geomechanics, Perth, pp. 299-308, ISBN 0-9756756-6-4.

Tibbett, M., Spain, A.V., Worrall, R., Tapsall, B. and Edmonds-Tibbett, T.L. (2010) Rehabilitation studies at the Ebenezer Mine, Ipswich, Queensland - 1998 to 2007, Volume III: Nutritional constraints to plant growth on six diverse materials, Unpublished report to Idemitsu Australia Resources Pty Ltd, Brisbane, Centre for Land Rehabilitation, The University of Western Australia, Perth, Report Reference: CLR-10-03-C/CSIRO Earth Sciences and Resource Engineering, Brisbane, Report: EP106665, 32pp., ISBN: 978-1-74052-200-7.

Weiersbye, I.M. (2007) Global review and cost comparison of conventional and phytotechnologies for mine closure, in Proceedings Second International Seminar on Mine Closure (Mine Closure 2007), A.B. Fourie, M. Tibbett and J.V. Wiertz (eds), 16-19 October 2007, Santiago, Chile, Australian Centre for Geomechanics, Perth, pp. 13-30, ISBN 978-0-9804185-0-7.

Worrall, R.C., Spain, A.V. and Tibbett, M. (2008) Establishment of native tree species on coal tailings - lessons from Ebenezer Mine, Queensland, Australia, in Proceedings Third International Seminar on Mine Closure (Mine Closure 2008), A.B. Fourie, M. Tibbett, I.M. Weiersbye and P. Dye (eds), 1417 October 2008, Johannesburg, South Africa, Australian Centre for Geomechanics, Perth, pp. 739-750, ISBN 978-0-9804185-6-9. 